\title{
LABOR AND THE EUROPEAN COMMUNITIES
}

\author{
MEYER BERNSTEIN*
}

I

\section{The European Coal and Steed Community}

The European Coal and Steel Community (E.C.S.C.) was the first-and for labor, up to the present moment, the most favorable-of the regional economic groupings which arose under the impetus to international cooperation given by the Marshall Plan.

\section{A. Labor Background}

The Schuman Plan was proposed at a time when social and political conditions made it necessary that labor support be secured in order to assure adoption and successful operation. This was especially so in the three major participating countries: the Western Zones of Germany, France, and Italy. In Germany, the trade unions had acquired a status and strength never before attained. The labor movement, as it were, was a kind of warranty that the Federal Republic was now democratic and denazified. During the early years of the occupation, political and business groups of all shades and descriptions eagerly sought labor's good will. This was particularly true of the coal and steel industries, which were fearful for their existence under allied control and directives. The dominant Christian party joined in this new appreciation of labor, and they all urged that labor be given equal power and influence in the management of these basic industries. This offer or promise was firm and explicit: the spokesmen for management made it in letters to the Unified Labor Organization; ${ }^{1}$ and the party, in an official program and in proposals to the state legislature of North Rhine-Westphalia. ${ }^{2}$

The British secured the Ruhr as their occupation zone; and, as soon as production of steel and coal began to get under way again, they put these new ideas of co-

* A.B. I936, Cornell University. International Affairs Director of the United Steelworkers of America. Author, The Hundred Largest Steel Conpanies in the Free World (1956); Steel Wages and Foreign Competition (I959); The I959 Steel Struke (I96I).

${ }^{1}$ The basic letters were sent by Dr. Jarres, chairman of the board of the Kloeckner-Werke A.G., and Reuse and Hilbert of the Gutehoffnungshuette, on Jan. 18, 1947, addressed to the Unified Labor Organization. The Jarres letter contained the following:

"... We therefore make on behalf of Kloeckner the following proposal:

"The Kloeckner-Werke board of directors shall be reconstituted on the principle of equality of 'Capital and Labor.' The representative of the employees should therewith together with the public receive the majority of the places [on the board] . ..." The full texts of the letters are given in ERIcH Potthoff, DeR KAMpf uM die Montan-Mitbestimmung 42-43 (I947). The title means: The Struggle for Codetermination in the Steel and Coal Industries.

The so-called Ahlener Program was adopted by the British Zone Conference of the C.D.U. (the Christian party) on Feb. I-3, 1947, and bills were introduced by the C.D.U. in the session of March $4-6$, 1947. One of the sponsors of these codetermination measures was Konrad Adenauer, who later became Chancellor. PorthoFf, op. cit. supra note $\mathrm{I}$, at 50-54. 
determination into effect on the level below their occupation control agencies. The main steel producers were decartelized into twenty-four so-called unit companies under the direction of a Steel Trustee Association manned by eleven Germans, four of them union men. Each unit company was organized under a board of directors and a board of officers. Each board of directors consisted of eleven men, with either just under or just over half of the board members for the different companies named by the union or the work council. In practice, the president and vice president of the work council (the German substitute for our local union), a member of the executive board or some other high functionary of the metalworkers' union, a member of the executive board or some other high functionary of the German Federation of Trade Unions, plus some man in public life friendly to the union, were named by labor to the board of directors of each company.

The eleven members of the Steel Trustee Association assumed the chairmanship of each of the twenty-four boards of directors. Most members became chairmen of the boards of directors of two companies. This meant, of course, that the four union members were also chairmen of the boards of directors of eight German steel companies, including some of the biggest, like Mannesmann.

The board of officers generally consisted of three persons of equal status: one was business director; the second, production director; and the third, labor director. In each case the labor director was named by the union. For the most part, these labor directors were former union officials, often district directors of the metalworkers' union. The labor director was given much more power than, say, a vice-president in charge of labor relations in the United States. In the first place, he was one of three officers and had equal power with the other two. He had no superior officer, since there was no president as in the United States. And finally, half of the members of the board of directors-and in almost half the companies the chairman of the board as well-were union men nominated by the same union organization which put him in office. Codetermination in the coal industry was somewhat weaker but nevertheless well-anchored.

All of this was introduced by the British and confirmed by the Americans when they assumed part of the responsibility for the iron and steel industry of Germany. Labor participation was also later extended to the government control agencies on which the Germans were represented. The deputy German member of the Ruhr Authority, for example, was selected on nomination of the German Federation of Trade Unions.

While adoption of the Schuman Plan was being discussed, the German labor movement was carrying on a campaign to incorporate the principles of codetermination into German law so that they would continue after the occupation ended. It is true that by this time the ardor of the dominant party and management for codetermination had cooled; nevertheless, the Parliament was ready-under some pressure from the unions and the Socialist Party, plus the union wing of the Christian party-to pass a law establishing codetermination in steel and coal along 
the same lines as under the occupation. The companies were now independent and had been returned to their previous owners. There no longer was a Steel Trustee Association, but, as before, half the members of the board of directors and one of the members of the board of officers were, in effect, to be named by the union. Today, therefore, the leading officers of the German Federation of Trade Unions and the Metalworkers' Union are members of the boards of directors of the German steel and coal companies. For example, Ludwig Rosenberg, vice president of the German Federation of Trade Unions, is also vice chairman of the board of directors of the Deutsche Edelstahlwerke; Otto Brenner, president of the Metalworkers' Union is vice chairman of the board of directors of the Krupp steel company; Heinrich Deist, the union's chief adviser on codetermination problems during the crucial period (and presently chief economic spokesman for the Social Democratic Party) is chairman of the board of directors of the Gusstahlwerke Bochumer Verein. Also, as before, the labor directors are all union men and have the same powers and prerogatives previously held. The labor directors are fulltime officers of the companies, retaining only their union memberships but not their former union positions. The union members of the boards of directors remain fulltime union functionaries, and only serve the companies at board meetings or other similar occasions.

The pattern for Germany had been set. It was clear, therefore, that if the Schuman Plan, which would cover exactly the same industries, was to be accepted, it had to have similar principles. This was acknowledged at the very outset by the German government's naming an executive board member of the German Federation of Trade Unions to be on the German delegation negotiating the details of the treaty with the other five countries.

In France and Italy labor had received no such recognition; but it was generally agreed that something had to be done there to overcome the Communist Parties and their captive trade unions. The Communists had, of course, denounced the Schuman Plan proposal as a capitalistic-imperialistic-monopolistic plot against the rights of workers. In each of these countries there were also non-Communist unions, either Christian or Socialist or Socialist-influenced. These were all numerically weaker than the Communist organizations, but, nevertheless, important as bulwarks of democracy. If the Schuman Plan was to succeed, these non-Communist unions had to be won over.

Combinations of the two situations-in Germany on the one hand, in France and Italy on the other-existed in the three other member nations: namely, Belgium, Holland, and Luxembourg. It was, therefore, relatively easy to give the European Coal and Steel Community strong pro-labor and even pro-free-union orientation, and, indeed, this is what happened.

\section{B. Treaty Provisions}

$\therefore$ The E.C.S.C. Treaty itself emphasizes the importance of labor in the Common Market. The first paragraph of article two reads: 
The mission of the European Coal and Steel Community is to contribute to the expansion of the economy, the development of employment and the improvement of the standard of living in the participating countries....

Title Three is devoted to "Economic and Social Provisions," and here, too, labor is given special consideration. For example, articles forty-six and forty-seven provide for consultation with interested parties. Continuing this theme, article forty-eight states: "The right of enterprises to form associations is not affected by this treaty...." But since employers' associations also participate in the Schuman Plan activities, the question arose as to what share labor has in their deliberations. So, to safeguard against possible lack of objectivity, article forty-eight goes on to stipulate:

The High Authority shall normally call upon producers' associations to obtain information which it requires or to facilitate the fulfillment of its objectives, provided that the associations in question either permit the properly chosen representatives of the workers and consumers to participate in the direction of these associations or in consultative committees attached to them, or in any other way give a satisfactory place in their organization to the expression of the workers' and consumers' interests.

One of the most important implementations of the social purposes of the European Coal and Steel Community is set forth in article fifty-six providing aid to labor displaced by changing conditions in the coal and steel industry. This article was found, however, to be inadequate; accordingly, it was amended in January I960.

Curiously enough, the German government, which has one of the most widespread programs in the field, objected to strengthening the clause and wished to place a time limit on it. The other five governments overruled the Germans. Following is the new addition to article fifty-six: ${ }^{3}$

Should profound changes in the marketing conditions of the coalmining or of the iron and steel industry, not directly connected with the introduction of the Common Market, make it necessary for certain enterprises permanently to discontinue, curtail or change their activities, the High Authority, at the request of the interested Governments,

(a) may, in accordance with the methods provided for in Article 54, facilitate the financing either in the industries under its jurisdiction or, with the agreement of the Council, in any other industry, of such programs as it may approve for the creation of new and economically sound activities, or for the conversion of enterprises, which are capable of assuring productive re-employment to workers rendered redundant;

(b) may grant non-repayable assistance as a contribution to

-the payment of compensation to tide the workers over until they can obtain new employment,

-the enabling of enterprises, by means of special grants, to pay their personnel during any temporary stand-offs necessitated by the change in their activities, -the granting of resettlement allowances to the workers,

-the financing of technical retraining for workers who are obliged to change their employment.

'E.c.s.c. High Authority, Eighth Generas Report on the Activities of the Community 293 (1960) [hercinafter cited as REPORT]. 
: The High Authority shall make the granting of nonrepayable assistance conditional upon the payment by the interested State of a special contribution at least equal to the amount of such assistance, unless an exception is authorized by a two-thirds majority of the Council.

The Treaty was to bring about profound changes in the industries affected. The end result, of course, was intended to be good, but precautions had to be provided for if the adjustment or transitional period was to be kept under control. The six countries, therefore, adopted a Convention containing the Transitional Provisions wherein chapter one of the General Provisions is entitled "Readaptation" and provides for the kind of aid which the Schuman Plan will make available to workers who are affected by the consequences of the introduction of the common market for coal and steel.

Following is the text of this section:

Chapter x. General Provisions. Readaptation. Section 23.

I. If the consequences of the establishment of the single market should oblige certain enterprises or parts of enterprises to cease or to modify their activity during the transition period defined in Section I of the present Convention, the High Authority, at the request of the interested governments and under the conditions specified below, shall furnish assistance in order to protect the workers from the burdens of readaptation and assure them a productive employment, and may grant non-reimbursable assistance to certain enterprises.

2. At the request of the interested governments and under the conditions defined in Article 46, the High Authority shall participate in a study of the possibilities of reemployment for unemployed workers either in existing enterprises or through the creation of new activities.

3. According to the procedure specified in Article 54, the High Authority shall facilitate the financing of approved programs submitted by the interested governments for the transformation of enterprises or for the creation, either in the industries coming under its jurisdiction or, with the concurrence of the Council, in any other industry, of new, economically sound activities capable of providing a productive employment for workers who have been released. Subject to the concurrence of the government concerned, the High Authority shall give preference in granting such facilities to the programs submitted by enterprises which have been obliged to cease their activity on account of the establishment of the common market.

4. The High Authority shall grant non-reimbursable assistance for the following purposes:

(a) to contribute, in case of total or partial closing of enterprises, to the payment of allowances to tide the workers over until they can find new employment;

(b) to contribute, by means of allotments to enterprises, to assuring the payment of their personnel in case of temporary unemployment necessitated by their change in activity;

$\therefore$ (c) to contribute to the payment of allowances to workers for reinstallation expenses;

(d) to contribute to the financing of technical retraining for workers obliged to change employment. 
C. The Practical Role of Labor

These Treaty provisions are, of course, substantial, but of equal importance is the manner in which labor participated in the Treaty's administration. This was achieved on several levels and had an immediate and continuing effect. First, two of the nine members of the High Authority have from the very beginning been men supported by labor and enjoying labor's confidence, and another one was added later.

In 1952, in accordance with its labor participation policy, the German government permitted the German Federation of Trade Unions to nominate one of the two German members of the High Authority, the chief executive organ of the Schuman Plan. The union submitted the name of Dr. Heinz Potthoff, who had previously served under its nomination on the Ruhr Authority, which, however, was to be abolished upon the introduction of the Schuman Plan. Dr. Potthoff had also served as chairman of the board of directors of a steel company, again on nomination of the union.

The second member of the High Authority from the labor movement is Paul Finet, who was formerly president of the International Confederation of Free Trade Unions. Finet was actually named not by a participating government but by the other eight members of the High Authority. The choice, however, was made by labor. Mr. Finet served one term as president of the High Authority. The third labor member of the High Authority, Mr. Roger Reynaud, comes from the French Christian union movement.

The High Authority has a staff of several hundred persons, many of whom are from the labor movement and some of whom hold very important posts. For example, the man called to direct the statistical services was Dr. Rolf Wagenfuehr. Dr. Wagenfuehr had formerly been with the Research Institute of the German Federation of Trade Unions. Dr. Potthoff's chief technical assistant, Dr. Willi Schwarz, came from the research department of the Metalworkers' Union of Germany.

Labor, of course, was most heavily concentrated in the division, Problems of Labor, under Mr. Finet; here union people from practically all of the six countries were given important assignments. Labor people, however, were also offered employment in many other divisions and often in key places. There is no quota system or anything of that nature in existence. Nevertheless, labor is highly represented.

Direct representation of labor, as such, is to be found in the Consultative Committee. The Consultative Committee is an organ of the Community whose opinion must be sought by the High Authority on all important decisions. It may on its own initiative institute action. It consists of fifty-one members-seventeen representing management in the Community's industries; seventeen representing consuming industries, such as railroads, metalworking industries and the like; and seventeen 
representing labor in the Community's industries. In addition, each group is entitled to one observer.

The labor members are chosen by the non-Communist coal and steel unions of the six countries. Although the Communists control the dominant labor organizations in France and Italy and are quite important in Luxembourg, they have been given no recognition whatever under the Schuman Plan. The chairmanship of the Consultative Committee rotates, so that from time to time union men occupy this office. Andre Renard, leader of the recent general strike in Belgium, has been a chairman of the Consultative Committee. So has Fritz Dahlmann, vice president of the German Mine Workers' Union. Of the eighteen union men on the Consultative Committee, thirteen come from the free or Socialist oriented unions, and five from the Christian.

Originally the Common Assembly of the E.C.S.C. consisted of seventy-eight members divided as follows: ${ }^{4}$ Germany, eighteen; France, eighteen; Italy, eighteen; Belgium, ten; the Netherlands, ten; and Luxembourg, four. When the Coal and Steel Community was supplemented by Euratom and the E.E.C., this Common Assembly of the Schuman Plan was superseded by a single European Parliament for all three Communities, in which the delegates were allocated as follows: ${ }^{6}$ Germany, thirty-six; France, thirty-six; Italy, thirty-six; Belgium, fourteen; the Netherlands, fourteen; and Luxembourg, six. At present delegates are all selected by the respective national parliaments, but provision is made for the preparation of proposals to accomplish election of delegates from each country by direct universal suffrage of its citizens. ${ }^{b}$ Among its other powers, the European Parliament is authorized by a two-thirds vote of its members to compel the resignation of the members of the High Authority of the E.C.S.C.?

Labor is represented in this supranational parliament through associated or friendly political parties. Moreover, several of the union men who serve in Germany as labor directors or members of boards of directors are members of the European Parliament. Eight functionaries of free or Socialist-oriented unions are currently members of the parliament, along with three or four from Christian-oriented unions. Only exponents of democracy have been named as delegates, and so there are no Communists in the European Parliament.

The Court of Justice, originally established for the E.C.S.C. but with its jurisdiction later extended to include the two other Communities, is another institution on which a labor man has served-however, in this case with only one justice out of seven. The only organ of the Schuman Plan on which labor is not directly repre-

\footnotetext{
$\therefore \quad$ E.C.S.C. Treaty art. 21.

"Convention Relating to Certain Institutions Common to the European Communities, arts. 1-2. See also E.E.C. Treaty art. 138 .

$\because$ "Convention, supra note 5, art. 2. In this same connection, compare article 21 of the E.C.S.C. Treaty with article 138 of the E.E.C. Treaty.

7 E.C.S.C. Treaty art. 24. A similar power exists to compel the resignation in a body of the members of the Commission of the E.E.C. See E.E.C. Treaty art. 144.
} 
sented is the Council of Ministers, consisting of one cabinet member from each of the six countries.

In this entire context care should be exercised in understanding the meaning of representation. When someone is employed by the High Authority, he owes his allegiance to that body and not to the organization from which he came. Nevertheless, it is foolish to ignore the effects of a person's antecedents or prior environment. Persons with labor background are, if nothing more, at least better able to understand labor's problems and point of view. They need not receive instructions from their former colleagues in order to be effective in protecting labor's interests.

\section{Labor Liaison}

In the six countries of the E.C.S.C., the unions of the industries covered by the Schuman Plan have organized themselves better to represent and promote labor's position. Both those organizations affliated with the International Confederation of Free Trade Unions (I.C.F.T.U.) and those affiliated with the International Confederation of Christian Trade Unions have set up liaison bureaus in the High Authority's capital of Luxembourg. The I.C.F.T.U. office was originally called the "Committee of 2r," for that was the number of participating organizations: one coal and one steel union from each of the six countries; one from each of the central federations of the six countries; one from the I.C.F.T.U.; and one from each of the international trade secretariats concerned-the International Metalworkers' Federation and the Miners' International Federation.

A permanent secretariat-originally under the direction of a Luxembourg steelworker-union official on a part-time basis, then under a Dutch union official on a full-time basis, and now under a German metalworker also on a full-time basiscoordinates the activities of the committee. Meetings are held normally just before a session of the Consultative Committee, to which most of the participants also belong. The secretariat would gather material and help formulate proposals, so that the union members of the Consultative Committee could be well informed with a prepared position. Special meetings were called to discuss important questions as they arose. Normally the top members of each affiliated union, including the president or vice president and generally accompanied by the union research director or economist, were in attendance. Between meetings of the "Committee of 2I," the secretariat would be in constant touch with the different agencies of the E.C.S.C. and particularly with the various divisions or departments of the High Authority. This was made easier because of the large number of union men on the staff of , the High Authority. Certainly there was no lack of opportunity for labor to make its infuence felt within the Schuman Plan, and this is indeed demonstrated by the record.

\section{E. Labor Benefits}

There are four major fields in which the European Coal and Steel Community has established policies or programs of direct benefit or interest to labor: (I) readaptation, (2) housing, (3) mobility, and (4) safety, health and hygiene. 


\section{Readaptation}

Prior to $x 952$, many coal mines and steel companies were actually submarginal and remained in operation only because of protection of one form or another from competition across the border. Under a free market, these companies could no longer survive, and the workers would lose their jobs. Therefore, provision was made to aid labor in readaptation to other forms of employment. Section twenty-three of the convention quoted earlier provides authority for such aid to labor. ${ }^{8}$

The following typical program covers over 50,000 German coal miners, many of them in mines belonging to steel companies, and provides for workers who lost their jobs as a result of discontinuance of their mine or department (in Germany, coke works are normally at the mine site):

\section{Discharged Workers ${ }^{9}$}

(a) A discharged worker finding himself unemployed is to be entitled to a tide-over allowance for one year, calculated on a descending scale for three periods of four months each, at 90,80 , and $70 \%$ respectively of his former monthly wage.

From this will be deducted unemployment and sickness benefit and any earnings totalling more than DM $40^{*}$ per month from activities exercised on the worker's own account or on that of another party.

(b) A worker undergoing retraining within twelve months from the date of his discharge will be entitled during such retraining to assistance at the first-period tide-over rate.

In addition, he will be refunded all expenses incurred in connection with his attendance at a retraining course approved by the labor exchange.

(c) A worker taking up employment in an industry other than the coal mining industry will be entitled to a differential allowance, making up his new wage for the first six months to $95 \%$ of his former wage, and for the following six months to $90 \%$.

Where a worker signed on at another pit is downgraded or put from piece rates to day wage rates, he will be entitled for six months to an allowance making up his new wage to $95 \%$ of his former wage.

Other provisions in the agreement

(a) A discharged worker called for interview by a prospective new employer is to be entitled to a refund of his travel expenses.

(b) For twelve months following discharge or transfer to another pit or branch of the enterprise, a worker will be refunded any additional travel expenses incurred as a result of his having to travel a greater distance to reach his work.

(c) Where the distance between a worker's new place of employment and his home is so great that he cannot cover it in both directions daily, he will be entitled to a separation allowance of DM 7.50 a day, and to a refund of the cost of one journey home per month.

(d) A worker compelled to change his residence in order to take up new employment will be refunded his travel expenses and those of his dependents, and his removal expensest in addition, he will be entitled to a resettlement allowance amounting to two months' wages. The resettlement allowance will be payable only within the twelve months following his discharge or transfer. As regards removal expenses, on the other hand, a

${ }^{8}$ See note 5 supra.

- Report 284-85.

* At that time a DM (Deutsche Mark) was worth 4.59 to the dollar. 
worker finding new employment within twelve months of his discharge may apply for a refund in respect of a removal up to two years from discharge.

(e) Over and above the tide-over, differential or retraining allowance, workers will receive a specified sum (DM 20 or DM io per month, according as they are or are not heads of households) in compensation for the loss of their entitlement to concessionary coal.

In addition, a worker who, having fulfilled the requirements for one or another of the various pension plans, voluntarily decides to retire early so that another worker can be kept on his job, would receive a lump sum of DM 3,000, plus DM 300 for each dependent child, and DM 240 as compensation for his loss of concessionary coal. An amount equal to one month's instalment of his friendly society pension ${ }^{8 a}$ will be deducted, up to a maximum of DM 500. Payment will be made as follows: one-half of the total sum on the day of departure, one-quarter on the first day of the seventh month and one-quarter on the first day of the tenth month following departure.

The provisions in Italy are somewhat different. There, 2,300 workers in all were discharged from twenty iron and steel enterprises in various parts of the country. The allowance in Italy is eighty-five per cent of the former salary, instead of the descending scale from ninety per cent to seventy per cent; it continues for fifteen months, instead of for one year. Furthermore, in case the worker finds employment, he shall receive the difference between his former wages and his new wages.

In France, a modification of this procedure was put into effect for a company which was in the process of reorganizing a department affecting ninety workers. ${ }^{10}$

... These men will not be discharged, but stood off temporarily, and will be entitled during the stand-off, under section $23(4)$ of the Convention, to an allowance equal to their former real wage, including bonuses. The reorganization is to take one year. The enterprise undertook not to discharge workers in receipt of the allowance either during the period for which this is payable or during the six months following.

Total credits made available by the High Authority of the European Coal and Steel Community for readaptation reached approximately $\$ 42,000,000^{11}$ as of February I0, I960, and covered II0,000 workers employed in r95 enterprises.

Authority for new programs expired this year, but was extended by the Parliament. As the High Authority's General Report states: ${ }^{12}$

The assistance granted by the High Authority, in cooperation with the Governments of the Member States concerned, has made it possible for the adjustments necessitated by the

oa The "friendly society pensions" referred to are those in the coal industry and are called "Knappschaftsversicherung." This refers to the special system of social security for the industry first established by law in 1923 and amended several times since then. It includes not only pensions but also sickness, childbirth, death, invalidity, and so on. It is financed by joint contributions-the employers paying a total of $26.8 \%$ of payroll up to certain limits, and the employees paying $\mathrm{rr} \%$.

${ }^{10}$ RePORT 287 .

11 The interested states must make a contribution at least equal to that of the High Authority.

19 REPORT 288-89. 
effects of the Common Market to go through without involving serious social disturbances. The measures taken, which were adapted as far as was at all possible to the special requirements of each case, helped the workers through the difficult period following their discharge, and in most cases made it easier for them to find fresh employment.

It was no doubt in consideration of the results obtained that the European Parliament and the employers' and workers' associations repeatedly expressed the hope that the High Authority would continue its readaptation work after the expiration of Section 23.

The support they gave the High Authority when it submitted its proposals for the revision of Article 56 of the Treaty was a valued encouragement to it.

Under the new article fifty-six of the Treaty, also quoted heretofore, ${ }^{13}$ this same kind of general action can now be taken on behalf of workers who lose their jobs as a result of automation or new technology.

\section{Housing}

One of the most urgent needs of labor in all Europe after the war was housing. Practically all European steel companies have housing programs for their employees. Desirable as this may be, there are nevertheless certain objections to living in a company house. The European Coal and Steel Community, therefore, decided to embark upon a housing program of its own.

The E.C.S.C. made a three-fold approach. ${ }^{14}$ First, it conducted a survey to ascertain the needs for worker housing. Second, it established a housing design competition to bring out the best possible forms of workers' housing. And, third, it established an intensive housing construction program.

The survey was done on a sample basis involving some 40,000 workers in the six-nation community. After the need was ascertained, the housing design competition was announced. By the closing date, August I, I959, plans had been submitted by 250 architects. Patrons of the competition were the housing ministers for the various countries involved. Each minister appointed an expert who, together with the others, settled the rules and conditions of the competition in cooperation with the International Union of Architects.

Plans were displayed at a special exhibition held in Luxembourg from December 7 to 18,1959 , and the winners received their prizes at a ceremony in the same city on December I7. The High Authority is bringing out a brochure on the results of the competition, containing studies by members of the panel of judges.

The housing construction program of the High Authority got under way before the survey and the design competition were completed. Up to January 1,1960 , the High Authority had approved arrangements to finance 44,987 dwellings in all. Of these, $24,85 \mathrm{I}$ were already completed; 14,285 , under construction; and $5,85 \mathrm{I}$, in preparation. The total amount set aside by the High Authority for this purpose up to the same date was $74,600,000$ units of account (i.e., American dollars). Of the 44,987 dwellings, 26,563 were intended to be let and $x 8,424$ to be available for ultimate ownership by their occupiers.

${ }^{18}$ Siè note 3 stspra.

14 REPORT 327-36. 
This program is part of a cooperative venture involving the High Authority of the Schuman Plan and various public credit institutions or funds of the participating countries. This is to say that the $\$ 74,600$,000 referred to above represented only a part of the total cost. In each country some other institution, such as a public savings scheme, the social security fund, or the like, would put up the rest of the money. Since these institutions had their own established interest rates, that portion made available by the High Authority would be subject to abnormally low interest in order to reach a more moderate average, and thus offset the higher going rate. For example, in a program in Germany, the social security institutions there made their money available at $5-5 \frac{1}{2}$ per cent. The High Authority, therefore, set a rate of 1.25 per cent on its own contribution. The social security share was DM $x 9.8$ million, and the High Authority's share DM 6.6 million. These monies are only a part of the total financing on this project of 3,200 dwellings. The total cost will approximate DM roo,000,000.

Unions are represented on the administration of the social security institutions; and, of course, the unions are also represented on the Coal and Steel Community. Thus, they have at least an equal participation with management in these housing programs. As a matter of fact, the unions' participation is direct, while management's is two or three degrees removed. Therefore, the housing which results from this program cannot be considered company housing. The program is still under way, and new projects are in preparation.

The programs just outlined are intended to provide homes for ordinary workers. In addition, however, there is the special case of workers whose plants or departments have been abolished and who have therefore been resettled on other jobs in other parts of the country. An example of this is the case of the Compagnie de Ateliers et Forges de la Loire, a steel company which transferred its operation from Assailly to St. Etienne. The workers, of course, were provided moving and other expenses, as discussed hereinbefore under the topic of Readaptation. But where were they to live when they reached St. Etienne? The High Authority, therefore, arranged with the French Government for a joint venture involving the French housing program's HLM Office (Habitations a loyer modéré-moderate cost housing program) to construct the roo necessary units for these workers on the basis of a forty-year loan.

\section{Mobility}

If, as the E.C.S.C. Treaty states, one of the missions of the Community is to harmonize conditions upward, then there must be mobility of labor among the six participating countries. Such free movement of labor is provided for under article sixty-nine of the Treaty:

r. The member States bind themselves to renounce any restriction, based on nationality, on the employment in the coal and steel industries of workers of recognized qualifications for positions in such industries possessing the nationality of one of the member States; this commitment shall be subject to the limitations imposed by the fundamental needs of health and public order. 
2. In order to apply these provisions, the member States will work out a common definition of skilled jobs and conditions of qualification, and will decide by common agreement upon the limitations provided for in the preceding paragraph. They will also work out administrative procedures which will permit offers of and demands for employment in the Community as a whole to be brought together.

3. In addition, for the categories of workers not falling within the provisions of the preceding paragraph and where an expansion of production in the coal and steel industries might be hampered by a shortage of suitable labor, they will adapt their immigration regulations as much as may be necessary to eliminate that situation; in particular, they will facilitate the reemployment of workers from the coal and steel industries of other member States.

4. They will prohibit any discrimination in payment and working conditions as between national and foreign workers, without prejudice to special measures concerning frontier workers; in particular, they will work out among themselves any arrangements necessary so that social security measures do not stand in the way of the movement of labor.

5. The High Authority must guide and facilitate the application by the member States of the measures provided for in this article.

. 6. This article shall not interfere with the international obligations of the member State.

Putting this article into effect involved overcoming enormous complexities. In the first place, it was not enough simply to provide that, for example, a Frenchman could move from Lorraine to the Ruhr. Provision had to be made for the equalization of his social security and other benefits, which he would want to enjoy upon retuining home. In consultation with the liaison bureau, the High Authority worked out a draft program which it then presented to the "Committee of 21 ." As it turned out, the High Authority was more liberal than the national unions; and, as a result, the original proposal had to be watered down considerably to meet the objections of union leaders who feared unwholesome effects upon their own membership at home. The fears turned out to be groundless and now there are thousands of foreigners working in the steel industries of Germany and Luxembourg.

\section{Safety, Health, and Hygiene}

For the first time, a whole multitude of problems affecting labor in the steel and coal industries can now be handled on an international basis with all the advantages of broad scale treatment and comparative study. Among the most important of these is safety, ${ }^{15}$ into which significant research is now possible. The High Authority can take advantage of the best available sources or can coordinate the individual projects in the participating countries.

Another field is hygiene and worker psychology, which were previously either neglected or treated on a limited basis. Industrial health and medicine have also been the subject of investigations which promise considerable success. For example, there is a program set up by the industrial health and medicine research committee

\footnotetext{
${ }^{15}$ REPORT 340-46.
} 
which has conducted studies in basic silicosis research, pneumonociosis in the iron and steel industry, carbon monoxide poisoning, work at high temperatures, noise abatement, dust prevention and suppression, and other subjects. These represent but a fraction of the kind of activities undertaken by the High Authority under the Schuman Plan.

\section{F. Shortcomings}

Labor, therefore, has reason to be proud of its achievements under the European Coal and Steel Community. Nevertheless, certain shortcomings have appeared. The close collaboration with management, both under national law and the aegis of the Community, has brought about a certain identification of viewpoint between official representatives of the union and management. Under such circumstances the interests of the workers themselves may not always receive the attention they deserve. For example, the writer once visited the scene of a coal disaster and attempted to ascertain the cause. The union leaders whom he interviewed insisted there was not any cause, that the company had done all it could for the safety of the men.

One of the reasons which unions have given for demanding an equal share in management, both on an industry and a supranational basis, was to prevent the kind of cartel building characteristic of the period between the wars. Yet the unions have done comparatively little to prevent a resurgence of the same movement. In fact, some of the union leaders, overconfident of their power to prevent abuse, have played a major role in generating public acceptance of concentration in the basic industries.

If anything, there may be an excess of at least one kind of labor participation. There are endless meetings-all with per diems and travel allowances-with the result that the real purpose of labor participation sometimes tends to become confused.

\section{G. Conclusion}

Nevertheless, it is clear that the European Coal and Steel Community has, on balance, brought about tremendous gains for the men and women employed in the basic steel and coal industries of the six countries. At the same time, it has strengthened the role of labor and has given the unions a sense of participation and responsibility never before exercised in a democracy. These objectives have been achieved to a reasonable degree. Most difficulties have been foreseen and provided for.

The Schuman Plan has become institutionalized and-as far as one can now judge-permanent. It is not socialism, and it is not paternalism. It can perhaps best be described as a kind of democratic welfare state. The Schuman Plan pattern of labor participation was only partially carried over into the European Economic Community, and scarcely at all into Euratom. 
II

\section{The European Economic Community}

\section{A. The Treaty Provisions}

The European Economic Community Treaty also contains, in article two, a reference to the standard of living, but it is very much weaker than that of the Schuman Plan. The Schuman Plan Treaty speaks of "the mission ... to contribute to ... the improvement of the standard of living ..." and goes on to effectuate this in a practical way. The E.E.C. article says:

It shall be the aim of the Community, by establishing a Common Market and progressively approximating the economic policies of Member States, to promote throughout the Community a harmonious development of economic activities, a continuous and balanced expansion, an increased stability, an accelerated raising of the standard of living and closer relations between its Member States.

And the implementation, except for the European Social Fund, is very meager. There is, for example, no concrete provision for housing construction. Labor has neither direct representation on the executive organ nor nearly the indirect impact it enjoys under the Schuman Plan. As a matter of fact, the labor unions have complained vociferously over their exclusion from policy-making functions. There is, of course, union participation, but most of this is limited to the European Social Fund. Labor is also represented on the Economic and Social Committee, but only as one of many categories of economic and social life. Furthermore, the Committee possesses only a restricted authority.

The European Social Fund is a device quite similar in purpose, but much more restricted in application, to the readaptation provisions of the Schuman Plan. Article I25 sets forth its purpose:

I. At the request of a Member State, the Fund shall, within the framework of the rules provided for in Article 127, cover $5^{\circ}$ per cent of expenses incurred after the entry into force of this Treaty by that State or by a body under public law for the purpose of:

(a) ensuring productive reemployment of workers by means of:

-occupational retraining,

-resettlement allowances; and

(b) granting aids for the benefit of workers whose employment is temporarily reduced or wholly or partly suspended as a result of the conversion of their enterprise to other productions, in order that they may maintain the same wage-level pending their full reemployment.

2. The assistance granted by the Fund towards the cost of occupational retraining shall be conditional upon the impossibility of employing the unemployed workers otherwise than in a new occupation and upon their having been, in productive employment, for a period of at least six months in the occupation for which they have been retrained.

The assistance granted in respect of resettlement allowances shall be conditional upon the unemployed workers having been obliged to change their residence within the Community and upon their having been in productive employment for a period of at least six months in their new place of residence. 
The assistance given for the benefit of workers in cases where an enterprise is converted shall be subject to the following conditions:

(a) that the workers concerned have again been fully employed in that enterprise for a period of at least six months;

(b) that the Government concerned has previously submitted a plan, drawn up by such enterprise, for its conversion and for the financing thereof; and

(c) that the Commission has given its prior approval to such conversion plan.

The Council of the European Economic Community has issued a regulation spelling out the operation of this fund. In part one, article one, of the Regulation, ${ }^{16}$ it is emphasized that the Social Fund's part is primarily to reimburse " $50 \%$ of the expenses incurred by the Member states or by bodies under public law . ..." for readaptation in its various forms. In other words, the initiative now is with the member countries rather than the Community. And benefits are less than under Schuman Plan programs. Furthermore, labor participation is limited to a committee consisting of representatives of governments and trade union and employer organizations.

\section{B. Labor Liaison and Criticism}

The International Confederation of Free Trade Unions has established a union secretariat for the three communities with headquarters in Brussels. The former head of the Luxembourg liaison bureau, Harm G. Buiter, is now general secretary of this office.

The unions, realizing the narrow treaty base upon which it must operate, place hope in the E.E.C. Commission for expanding the functions of the Economic and Social Committee and at the same time strengthening labor's role in it and in the executive. They also call for democratization of the European Parliament by direct election of its membership. ${ }^{17}$ In this way, the unions hope to bring to bear on the E.E.C. some of the prestige they already possess in the Schuman Plan.

On the positive side the unions admit that, in consolidating the statistical services. of the three communities under the former Schuman Plan personnel, the many benefits of a reliable and comprehensive survey are now made available on the basis: of the whole economic picture, rather than being limited to the coal and steel industries. Another stride forward for labor was the election on September 29, I960, of Ludwig Rosenberg, vice president of the German Federation of Trade Unions, to the presidency of the Economic and Social Committee for a term of two years.

\section{Conclusion}

The European Economic Community is too new to permit a definitive judgment on the role of labor. In fact, as far as labor is concerned, it is still in the developmental stage. Although lacking a treaty base-such as exists in the Schuman Plan-

\footnotetext{
${ }^{16}$ Council of the E.e.C., Regulation No. 9, Concerning the European Social. Fund, Pub. No. $342 / 60-\mathrm{E}(\mathrm{x} g 60)$.

${ }^{17}$ Declaration on European Integration by the International Confederation of Free Trade Unions" European Union Secretariat, Brussels, Belgium, Nov. 28, 1960.
} 
the European unions hope eventually to raise their status in the E.E.C. to the same level. They believe this can be done in two ways; first, by liberal interpretation of the E.E.C. Treaty; and, second, by consolidating organs and offices of the three Communities into one for the sake of efficiency. If, for example, the High Authority of the Schuman Plan and the Commission of the E.E.C. become identical, then it is fair to assume that at least one of the labor men on the former will be carried over into the new executive body. And the same principle applies to the administrative staff. Labor, therefore, can expect to receive more and more recognition in the European Economic Community, though perhaps never quite so much as it enjoys in the Schuman Plan.

\section{III}

\section{Euratom}

The role of labor in this third of the communities is peripheral. The European Atomic Energy Community is the most parochial of the three, and has the least direct impact on labor. This circumstance is reflected in the Euratom Treaty, which is almost bare of references to working people or their organizations. Again the aim is to raise living standards, but here only "by the creation of conditions necessary for the speedy establishment and growth of nuclear industries."18 There may be schools for training specialists, and provisions for safety and health.

The only real labor participation is on the Economic and Social Committee, which under the terms of the Convention signed on March 25, 1957, will have a common membership and operation with that of the European Economic Community. Thus, Ludwig Rosenberg, vice president of the German Federation of Trade Unions has not only been elected chairman of the Economic and Social Committee of the E.E.C, but for Euratom as well. Also, if labor succeeds in expanding the functions and effectiveness of this committee, it will in the same measure apply to Euratom. Otherwise labor has little recognition in this presently smallest, though potentially most promising, of the three communities. Thus, for labor, the model remains the Schuman Plan, which is still a rarity for union participation on such a scale in the free world today.

\footnotetext{
${ }^{18}$ Euratom Treaty art. I.
} 